\title{
Effects of environmental salinity on carbon isotope discrimination and stomatal conductance in Spartina grasses
}

\author{
Brian R. Maricle*, Raymond W. Lee \\ School of Biological Sciences, Washington State University, PO Box 644236, Pullman, Washington 99164-4236, USA
}

\begin{abstract}
High salinity levels have long been recognized as an important environmental factor influencing plant growth and performance. Salt stress and concomitant water stress are likely to affect photosynthesis by reductions in stomatal conductance necessary to prevent loss of water vapor. Despite inundation with saline water, salt marsh communities exhibit high primary productivity. This study tested the effects of 0 to $40 \%$ salinity on leaf carbon isotope discrimination $(\Delta)$, leaf stomatal conductance $\left(g_{\mathrm{s}}\right)$, and leaf conductance to $\mathrm{CO}_{2}\left(g_{\mathrm{CO}_{2}}\right)$ in the emergent estuarine $\mathrm{C}_{4}$ grasses Spartina alterniflora, $S$. anglica, and $S$. patens. $\Delta$ increased with increasing salinity in greenhouse and growth chamber experiments. $g_{\mathrm{s}}$ and $g_{\mathrm{CO}_{2}}$ peaked at moderate salinity levels (10 to $20 \%$ ) but significantly decreased at higher salinities in all species.
\end{abstract}

KEY WORDS: Salt stress $\cdot$ Photosynthesis $\cdot$ Spartina $\cdot \delta^{13} \mathrm{C} \cdot$ Stable isotopes

\section{INTRODUCTION}

The high and fluctuating salinity levels that characterize coastal salt marshes can strongly affect plant productivity (Drake 1989). Cordgrasses of the genus Spartina (Poaceae) flourish in many estuarine marsh communities and are apparently highly tolerant of saline conditions. Spartina grasses are the dominant component of many salt marsh communities (Teal \& Teal 1969) and are important contributors to estuarine food webs in native ranges (Peterson et al. 1985). The importance of Spartina species in estuarine communities makes understanding the effects of salinity on Spartina relevant in considerations of marsh health and production.

Saline soils decrease a plant's ability to take up water by increasing the osmotic strength of the soil. This is similar mechanistically to drought stress; both parameters are often incorporated with measures of water potential $(\Psi)$. Elevated soil salinity causes low $\Psi$ and concomitant water stress to plants (Jennings 1976). Stomatal aperture is sensitive to changes in $\Psi$, so stomatal conductance is often reduced when environmental $\Psi$ is lowered (Willmer 1983). Therefore stomatal closure usually accompanies drought and salt stress. A decrease in stomatal conductance can reduce incoming $\mathrm{CO}_{2}$ and thus reduce photosynthetic rates.

Stable isotope techniques are useful in studying carbon metabolism involved with photosynthesis (Farquhar et al. 1989) and plant water-use efficiency (WUE; Farquhar \& Richards 1984). Past studies have found that carbon isotope discrimination $(\Delta)$ and WUE are tightly related because both parameters depend on stomatal aperture (Farquhar et al. 1982a). This relationship is easily demonstrated in $\mathrm{C}_{3}$ species (Farquhar \& Richards 1984) because of large carbon discriminations resulting from Rubisco fractionation ( $\mathrm{O}^{\prime}$ Leary 1981). This $\Delta$-WUE relationship is also present in $C_{4}$ species, but to a lesser degree than in $\mathrm{C}_{3}$ plants because of limited Rubisco discrimination and smaller 
variations in internal $\mathrm{CO}_{2}$ concentrations (Farquhar 1983, Henderson et al. 1998). Despite the importance of salinity in the salt marsh environment, the effect of salinity on $\Delta$ and WUE in estuarine grasses is presently unknown.

Leaf stable carbon isotope values can be used to determine the degree to which stomatal conductance is affected by salinity-induced water stress. Previous studies have shown a decrease in ${ }^{13} \mathrm{C}$ discrimination with increasing salinity in $\mathrm{C}_{3}$ plants (e.g. Farquhar et al. 1982b, Neales et al. 1983, Brugnoli \& Lauteri 1991, van Groenigen \& van Kessel 2002). The opposite trend has been observed in a few salt-stressed terrestrial $\mathrm{C}_{4}$ species (Bowman et al. 1989, Meinzer et al. 1994, Sandquist \& Ehleringer 1995, Zhu \& Meinzer 1999), but has not previously been demonstrated in estuarine species. In $\mathrm{C}_{4}$ plants, a negative fractionation involved with $\mathrm{CO}_{2}$ hydration (O'Leary 1981) leads to increasing discrimination against ${ }^{13} \mathrm{C}$ in response to increasing salt levels, leading to more negative $\delta^{13} \mathrm{C}$ in plant tissues.

Salt marsh communities occur at coastal locations where fresh- and saltwater mix. Soil salinities in wellmixed areas will normally be 15 to $25 \%$ o.g. Bertness \& Ellison 1987), but can be greater in high marsh areas where evaporative stresses are high (Pennings \& Bertness 2001), sometimes up to a marine level of $35 \%$ or slightly higher. Since halotolerant salt marsh grasses encounter chronic (and fluctuating) salinity stress, it is likely that the increased ${ }^{13} \mathrm{C}$ discrimination signal will be present in leaves, and that this signal will provide an integrated measure of salinity stress during plant growth. In this study, leaf stomatal conductance $\left(g_{\mathrm{s}}\right)$, leaf conductance to $\mathrm{CO}_{2}\left(g_{\mathrm{CO}_{2}}\right)$, and carbon isotope discrimination $(\Delta)$ were measured in the emergent estuarine $\mathrm{C}_{4}$ grasses Spartina alterniflora Loisel., $S$. anglica C.E. Hubbard, and S. patens (Aiton) Muhl. grown under 0 to $40 \%$ salinity in greenhouse and growth chamber studies. Differences in these parameters were anticipated from salinity-induced changes in photosynthetic properties.

\section{MATERIALS AND METHODS}

Plants were collected for experimentation from field sites and were maintained under greenhouse and growth chamber conditions. Spartina alterniflora was collected in Willapa Bay, Washington $\left(46^{\circ} 35^{\prime} \mathrm{N}\right.$, $\left.124^{\circ} 01^{\prime} \mathrm{W}\right), S$. anglica was collected in northern Puget Sound, Washington $\left(48^{\circ} 15^{\prime} \mathrm{N}, 122^{\circ} 26^{\prime} \mathrm{W}\right)$, and $S$. patens was obtained from the Gulf of Mexico near Panacea, Florida $\left(30^{\circ} 02^{\prime} \mathrm{N}, 84^{\circ} 23^{\prime} \mathrm{W}\right)$.

Tillers from all plants were potted individually in a 50/50 (v/v) sand/potting soil mixture and were watered to saturation twice weekly with modified Hoagland nutrient solution (Epstein 1972). Plants were allowed $30 \mathrm{~d}$ to acclimate to these conditions before initiating the experiment. Due to space constraints, plants were separated into 2 populations: plants were either grown in a greenhouse or in a walk-in growth chamber. The greenhouse was well ventilated and conditions consisted of natural lighting (average irradiance was $400 \mu \mathrm{mol}$ quanta $\mathrm{m}^{-2} \mathrm{~s}^{-1}$ during daylight hours, with peaks near $1500 \mu \mathrm{mol} \mathrm{m}^{-2} \mathrm{~s}^{-1}$ on sunny days) with $26^{\circ} \mathrm{C}$ daytime temperatures and $18^{\circ} \mathrm{C}$ at night. Growth chamber conditions were a $14 \mathrm{~h}$ photoperiod with $26^{\circ} \mathrm{C}$ days and $18^{\circ} \mathrm{C}$ nights. Light was provided by $400 \mathrm{~W}$ metal halide lamps with irradiance about $300 \mu \mathrm{mol}$ quanta $\mathrm{m}^{-2} \mathrm{~s}^{-1}$ at bench level.

Plants were randomized between treatments and were placed into large plastic tubs (12 pots per tub in an unbalanced block design; 4 to 6 tubs per treatment) and flooded with enough water to submerge plants to a level $2 \mathrm{~cm}$ above the soil surface (about $12 \mathrm{l}$ per tub). The water was completely replaced weekly. During the acclimation period, salinity levels were increased $10 \% \mathrm{wk}^{-1}$ until treatments included $0,10,20,30$, and $40 \%$ salt in greenhouse plants and 0,15 , and $30 \%$ salt in growth chamber plants (Instant Ocean salts; Aquarium Systems). After proper salinity levels were reached, plants grew at least $30 \mathrm{~d}$ in their respective treatments before measurements were made.

$g_{\mathrm{s}}$ was measured in greenhouse plants with an LI1600 steady state porometer (LI-COR). Measures of $g_{\mathrm{s}}$ were made on each plant during mid-day hours on clear days between 23 May and 4 June 2005. Total leaf vapor conductance $\left(g_{\mathrm{v}}\right)$ is a more inclusive measure that also accounts for boundary layer conductance $\left(g_{\mathrm{a}}\right)$, and is therefore relevant to measures of $\mathrm{CO}_{2}$ assimilation $\left(g_{\mathrm{CO}_{2}}=0.625 g_{\mathrm{v}}\right.$, Salisbury \& Ross 1992). $g_{\mathrm{v}}$ was calculated after Campbell \& Norman (1998) as:

$$
g_{\mathrm{v}}\left(\mathrm{mol} \mathrm{m}^{-2} \mathrm{~s}^{-1}\right)=\frac{1}{1 / g_{\mathrm{s}}+1 / g_{\mathrm{a}}}
$$

$g_{\mathrm{a}}$ was calculated after Campbell \& Norman (1998) as:

$$
g_{\mathrm{a}}\left(\mathrm{mol} \mathrm{m}^{-2} \mathrm{~s}^{-1}\right)=(0.147) \sqrt{\frac{u}{d}}
$$

where $u$ is wind speed $\left(\mathrm{m} \mathrm{s}^{-1}\right)$, measured with a Traceable ${ }^{\circledR}$ hot wire anemometer (Control Company), and $d$ is the characteristic dimension of the leaf, found by multiplying 0.72 by the maximum leaf width (Campbell \& Norman 1998). Measures of $g_{\mathrm{CO}_{2}}$ allow researchers to calculate $\mathrm{CO}_{2}$ assimilation rates $(A)$ with simple models, e.g. $A=g_{\mathrm{CO}_{2}}\left(C_{\mathrm{a}}-C_{\mathrm{i}}\right)$, where $C_{\mathrm{a}}$ and $C_{\mathrm{i}}$ are ambient and intercellular concentrations of $\mathrm{CO}_{2}$ 
(Salisbury \& Ross 1992). Since $\mathrm{CO}_{2}$ levels within the greenhouse were likely not equal to ambient, we present only conductances and not $A$.

Plants were maintained for 60 to $80 \mathrm{~d}$ in their respective salinity treatments. During this time, plants increased their fresh weight biomass from 250 to $800 \%$. Therefore, carbon isotope measurements on all but the oldest leaves represented carbon fixed during the experimental growth period. At harvest, 2 complete middle-aged leaves were sampled from similar-sized shoots from all plants for subsequent isotope analysis. The leaves were dried at $65^{\circ} \mathrm{C}$ for 2 to $3 \mathrm{~d}$, then ground to powder with a mortar and pestle. Stable carbon isotope composition was determined using a Eurovector elemental analyzer interfaced with a continuous flow Micromass Isoprime isotope ratio mass spectrometer. Routine precision for the instrument was $\pm 0.06 \%$ for $\delta^{13} \mathrm{C}$. Average $\delta^{13} \mathrm{C}$ values for source $\mathrm{CO}_{2}$ were obtained by sampling mid-day air in growing locations with evacuated gas-sampling vials. The absolute $\delta^{13} \mathrm{C}$ values of plants grown in the growth chamber were slightly lower than $\delta^{13} \mathrm{C}$ values of greenhouse plants due to differences in source $\mathrm{CO}_{2}$. The growth chamber used in this study received air originating in the building ventilation system that was lighter $\left(\delta^{13} \mathrm{C}=-10.7 \%\right.$ ) than $\mathrm{CO}_{2}$ measured in the greenhouse $\left(\delta^{13} \mathrm{C}=-9.5 \%\right)$. For this reason, absolute $\delta^{13} \mathrm{C}$ values of greenhouse or growth chamber plants reflect source $\mathrm{CO}_{2}$ while differences among salinity treatments reflect physiological isotope effects. Therefore, discrimination $(\Delta)$ values were calculated so that both groups of plants could be analyzed together. $\Delta$ was calculated as:

$$
\Delta=\delta^{13} \mathrm{C}_{\text {source }}-\delta^{13} \mathrm{C}_{\text {product }}
$$

where $\delta^{13} \mathrm{C}_{\text {source }}$ is the $\delta^{13} \mathrm{C}$ value of ambient $\mathrm{CO}_{2}$ and $\delta^{13} \mathrm{C}_{\text {product }}$ represents the $\delta^{13} \mathrm{C}$ of carbon fixed into plant tissue (O'Leary et al. 1992). The effect of salinity on $\Delta$ was measured for each species using analysis of variance. In these models, treatments were blocked by growing location. Multiple individuals were averaged within each tub. $g_{\mathrm{s}}$ and $g_{\mathrm{CO}_{2}}$ measures were compared between species and treatments using analysis of variance; in these models, treatments were blocked by tub (SAS v8.0; $\alpha=0.05$ ).

\section{RESULTS}

A significant increase in $\Delta$ was observed with increasing soil salinity in all Spartina spp. (Fig. 1). Unlike many other studies, we observed very little mortality in higher salinity treatments because plants were slowly acclimated to increased salinity conditions. Leaf $\Delta$ values became more positive as a function of increasing salinity (ANOVA, $\mathrm{p}<0.042$ ). Overall $\Delta$ shifts for Spartina spp. were nearly $2 \%$ across the 0 to $40 \%$ salinity gradient.

Leaf $\delta^{13} \mathrm{C}$ ranged from -12.1 to $-15.6 \%$ in greenhouse plants and from -13.6 to $-17.7 \%$ in growth chamber plants. These $\delta^{13} \mathrm{C}$ values are slightly more negative than the $-13.5 \%$ typically found in $\mathrm{C}_{4}$ leaves (O'Leary 1981), reflecting the difference in $\delta^{13} \mathrm{C}$ of source $\mathrm{CO}_{2}$ between ambient $\left(\delta^{13} \mathrm{C}=-8 \%\right.$, greenhouse $\left(\delta^{13} \mathrm{C}=-9.5 \%\right)$, and growth chamber $\left(\delta^{13} \mathrm{C}=\right.$ $-10.7 \%$ o). Differences in $\Delta$ represent physiological responses to salinity and were uniform between greenhouse and growth chamber plants.

Mean $g_{\mathrm{s}}$ ranged from 0.02 to $0.23 \mathrm{~mol} \mathrm{~m}^{-2} \mathrm{~s}^{-1}$ across species and treatments (Fig. 2). $g_{\mathrm{s}}$ peaked at moderate salinities (10 to $20 \%$ ) but was significantly decreased

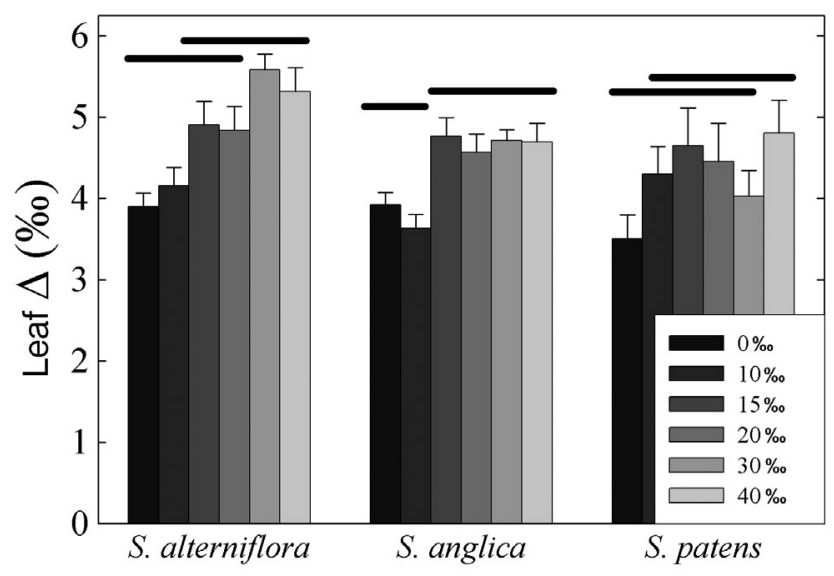

Fig. 1. Spartina spp. Carbon isotope discrimination (\%) in leaf tissues of flooded-treatment plants grown under salinities ranging from 0 to $40 \%$. Shown is the least squares mean of 3 to 5 individuals $\pm \mathrm{SE}$. Lines over the bars represent significant differences at $\alpha=0.05$ (Scheffe adjustment)

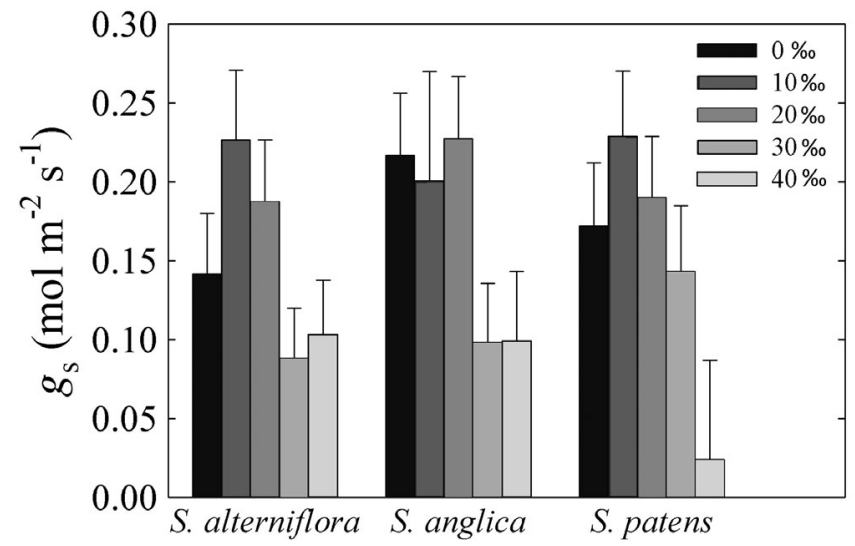

Fig. 2. Spartina spp. Effect of increasing salinity on leaf stomatal conductance $\left(g_{\mathrm{s}}\right)$ given as the least squares mean $\pm \mathrm{SE}$ of 3 to 5 individuals 
at higher salinities across species. There were no significant differences between species (ANOVA, $\mathrm{p}=$ $0.503)$ or the species $\times$ treatment interaction $(\mathrm{p}=$ 0.380), indicating all species responded similarly to increasing salinity. $g_{\mathrm{s}}$ in the 10 and $20 \%$ o treatments was significantly greater than in the 30 and $40 \%$ treatments ( $\mathrm{p} \leq 0.046$; Scheffe adjustment). $g_{\mathrm{CO}_{2}}$ ranged from 0.03 to $0.14 \mathrm{~mol} \mathrm{~m}^{-2} \mathrm{~s}^{-1}$ (data not shown). Air currents in the greenhouse were enough to make $g_{\mathrm{a}}$ almost negligible, making $g_{\mathrm{s}}$ the primary contributor to $g_{\mathrm{v}}$ and hence $g_{\mathrm{CO}_{2}} \cdot g_{\mathrm{CO}_{2}}$ closely paralleled $g_{\mathrm{s}}$ (correlation, $\mathrm{r}=0.957) \cdot g_{\mathrm{CO}_{2}}$ also peaked at moderate salinities (10 to $20 \%$ ) and significantly decreased at higher salinities across species (ANOVA, $p \leq 0.002$ ). If one assumed ambient $\mathrm{CO}_{2}$ concentrations of $370 \mathrm{ppm}$ and $C_{\mathrm{i}} / C_{\mathrm{a}}$ ratios near 0.36 (Henderson et al. 1998), $\mathrm{CO}_{2}$

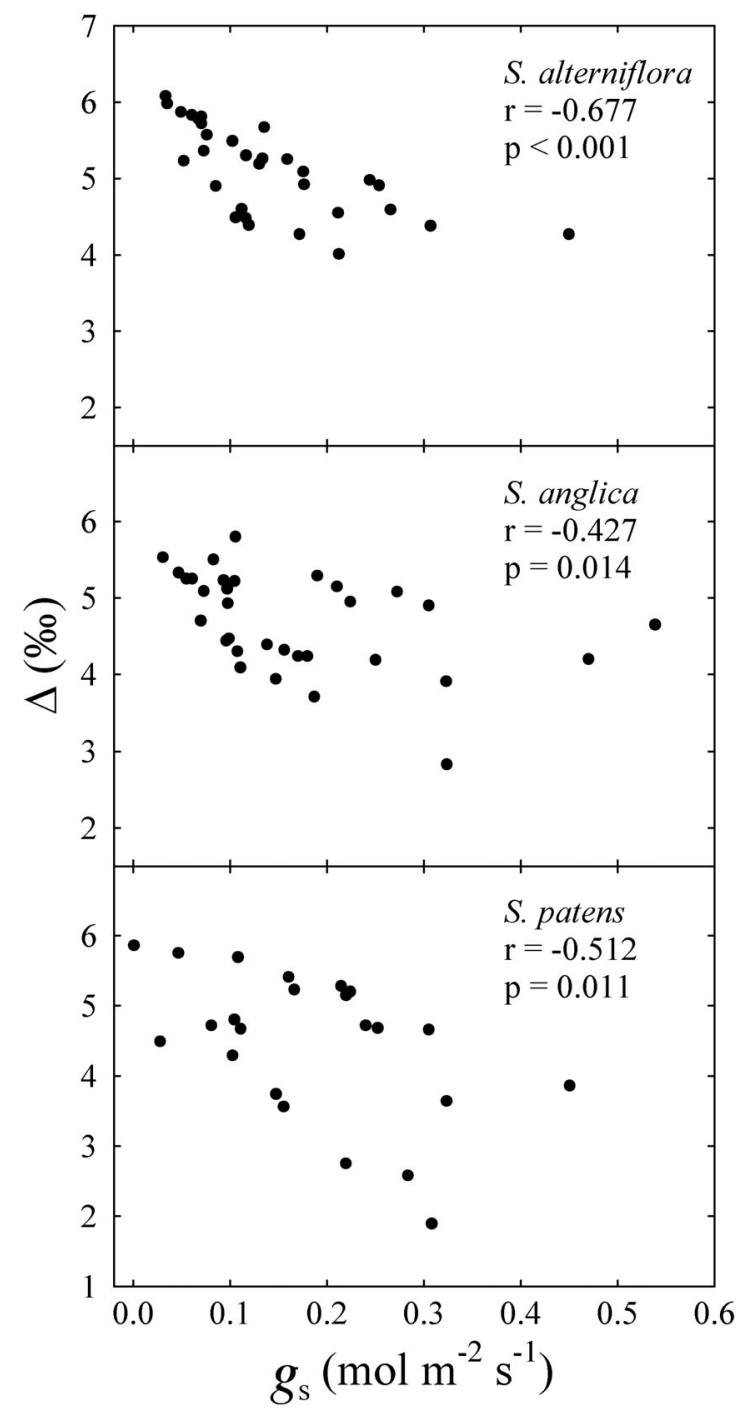

Fig. 3. Spartina spp. Relationship of discrimination $(\Delta)$ to leaf stomatal conductance $\left(g_{\mathrm{s}}\right)$ assimilation values in the present study would be similar to previously published measures for $\mathrm{CO}_{2}$ uptake by Spartina pectinata under salinity stress (Heckathorn \& DeLucia 1991).

Increasing salinity led to increases in $\Delta$ and decreases of $g_{\mathrm{s}}$ across species. There was a significant, indirect relationship between $g_{\mathrm{s}}$ and $\Delta$ in greenhouse plants in all 3 species (Fig. 3; correlation, p $\leq 0.014$ ).

\section{DISCUSSION}

High salinity is an important factor influencing plant growth in estuaries. Most halophytes are facultative (Zhu 2001); there may be no obligate halophytes among the Angiosperms (Barbour 1970). Therefore salt is a burden for all plants. Understanding the physiological effects of salt on photosynthetic parameters of a dominant salt marsh species may provide insights into carbon fixation and estuarine production.

The Spartina spp. in this study showed a $\Delta$ increase of up to $2 \%$ with increasing salinity. This change in $\Delta$ is similar to results presented for Atriplex lentiformis (Zhu \& Meinzer 1999) in response to a similar salinity gradient. Similar-sized increases in $\Delta$ have been measured under smaller salinity increases in other $\mathrm{C}_{4}$ species, including Atriplex confertifolia (Sandquist \& Ehleringer 1995), Saccharum spp. hybrids (Meinzer et al. 1994), Zea mays, and Andropogon glomeratus (Bowman et al. 1989). However, the trend observed in the present study was opposite the results presented by Walker \& Sinclair (1992) for Atriplex vesicaria and A. stipitata (also see discussion by Sandquist \& Ehleringer 1995).

Farquhar (1983, modified by Henderson et al. 1992) proposed the following model to predict ${ }^{13} \mathrm{C}$ discrimination in $\mathrm{C}_{4}$ plants:

$$
\Delta=a+\left[b_{4}+\Phi\left(b_{3}-s\right)-a\right]\left(C_{\mathrm{i}} / C_{\mathrm{a}}\right)
$$

In this model, $a$ is the carbon fractionation due to diffusion of $\mathrm{CO}_{2}$ in air $(4.4 \%), b_{4}$ is the fractionation by $\mathrm{PEP}$ carboxylase and from dissolution of $\mathrm{CO}_{2}$ to $\mathrm{HCO}_{3}^{-}$ (about $-5.7 \%$ at $25^{\circ} \mathrm{C}$ ), $b_{3}$ is fractionation by Rubisco $(29 \%), \Phi$ is the proportion of $\mathrm{CO}_{2}$ that leaks out of the bundle sheath cells, $s$ is the fractionation of $\mathrm{CO}_{2}$ during leakage from bundle sheath cells $(1.8 \%)$, and $C_{\mathrm{i}} / C_{\mathrm{a}}$ is the ratio of internal to ambient partial pressures of $\mathrm{CO}_{2}$. Under physiological conditions, all factors will remain constant except $\Phi$ and $C_{\mathrm{i}} / C_{\mathrm{a}}$ (Farquhar 1983). Therefore, variations in $\Delta$ in $C_{4}$ plants will reflect changes in $\Phi$ or $C_{\mathrm{i}} / C_{\mathrm{a}}$.

The $\mathrm{C}_{4}$ grasses in this study showed increases in carbon isotope discrimination $(\Delta)$ with increasing salinity. According to the above model, decreases in $C_{\mathrm{i}} / C_{\mathrm{a}}$ or increases in $\Phi$ will lead to increased $\Delta$ (when $\Phi$ 
$<0.32$, Sandquist \& Ehleringer 1995). In this study, all species showed a significant decrease in stomatal conductance with increasing salinity (Fig. 2). Whereas decreasing $g_{\mathrm{s}}$ may suggest decreasing $C_{\mathrm{i}} / C_{\mathrm{a}}$, previous studies have shown that $C_{\mathrm{i}} / C_{\mathrm{a}}$ values did not change with increasing salinity in $\mathrm{C}_{4}$ plants (Bowman et al. 1989, Meinzer et al. 1994). In the present study, a significant relationship was found between $\Delta$ and $g_{\mathrm{s}}$ (Fig. 3). This may suggest a role of $g_{\mathrm{s}}$ in determining $\Delta$ in these marsh halophytes. However, quantum efficiency measures on Distichlis spicata and numerous Spartina spp. indicate $\Phi$ increases with salinity (Long \& Baker 1986, B. R. Maricle et al. unpubl.). Additionally, $C_{\mathrm{i}} / C_{\mathrm{a}}$ values in $\mathrm{C}_{4}$ plants depend on more than just $g_{\mathrm{s}}$. An increase of $\Phi$ with unchanging $C_{\mathrm{i}} / C_{\mathrm{a}}$ suggests salinity may act to increase internal cycling of $\mathrm{CO}_{2}$ in salt-stressed $\mathrm{C}_{4}$ species. Perhaps one physiological feature contributing to salt tolerance in $\mathrm{C}_{4}$ monocots is an ability to cycle $\mathrm{CO}_{2}$ internally as an outlet for excess light energy when $g_{\mathrm{s}}$ is low.

Plant sensitivity to salt may be indicated by the magnitude with which $\Delta$ changes over increasing salinity. Only one other study (involving a single terrestrial salt flat species), has investigated $\Delta$ changes in response to salinities as high as full strength seawater (Zhu \& Meinzer 1999). The $2 \%$ change in $\Delta$ observed over a gradient of freshwater to $40 \%$ salt $(\sim 600 \mathrm{mM})$ in Spartina spp. is comparable to the 1.5 to $3 \%$ change in $\Delta$ observed over much narrower $\mathrm{NaCl}$ gradients ( $\leq 85 \mathrm{mM}$ ) in Saccharum spp. (Meinzer et al. 1994), Zea mays, or Andropogon glomeratus (Bowman et al. 1989). This would indicate that stomatal conductance and $\Phi$ are much less sensitive to salinity in Spartina spp. grasses compared with these species. In terrestrial Atriplex species, the effect of salinity on $\Delta$ appears to be variable. A range of salt concentrations up to $\sim 52 \mathrm{mM}$ resulted in a $2 \%$ change in $\Delta$ in the salt tolerant Atriplex confertifolia (Sandquist \& Ehleringer 1995), whereas in A. lentiformis exposure to 0 to $600 \mathrm{mM} \mathrm{NaCl}$ was required to induce a $2 \%$ change in $\Delta$ (Zhu \& Meinzer 1999).

The relationship between salinity and $\Delta$ may be used to make inferences about primary production of marsh grasses during a growing season. If atmospheric $\delta^{13} \mathrm{C}$ values are monitored seasonally, one can determine amounts of growth that occurred under various salinity levels by determining how much leaf carbon falls into established categories of $\Delta$. This relationship also would allow researchers to reconstruct changes in the seasonal salinity status if plant growth rates are known. Conversely, if seasonal changes in salinity are known, one can calculate growth rates of plants, providing one knows the patterns of $\delta^{13} \mathrm{C}$ occurring over the length of grass blades (Sasakawa et al. 1989, Meinzer \& Saliendra 1997). Fluctuations in leaf $\delta^{13} \mathrm{C}$ have been observed along the length of field collected Spartina spp. blades. Over a growing season, leaf $\delta^{13} \mathrm{C}$ values in field-collected $S$. alterniflora plants increased ( $\Delta$ decreased) by 1 to $1.5 \%$, moving toward the younger tissue near the intercalary meristem at the base of the leaf (B. R. Maricle \& R. W Lee unpubl. data). This pattern has been attributed to changes in the ratio of PEP carboxylase to Rubisco activity in maize leaves (Sasakawa et al. 1989) and to changes in stomatal conductance and photosynthetic rates in sugarcane leaves (Meinzer \& Saliendra 1997). If this slope is corrected for, researchers can monitor changes in plant $\delta^{13} \mathrm{C}$ against changes in atmospheric $\delta^{13} \mathrm{C}$, producing $\Delta$ values that may correlate with environmental factors such as salinity. Since grass blades grow from a basal meristem, these variations may reflect environmental changes during the growth season in a manner analogous to tree rings (Helliker \& Ehleringer 2002).

Acknowledgements. The authors thank C. Cody for greenhouse assistance; M. A. Evans and P. A. Rabie for help with statistics; K. Patten, S. D. Hacker, and C. E. Hellquist for providing plants; and 3 anonymous reviewers for valuable criticisms on the manuscript. This project was partially funded by the Betty W. Higinbotham Trust, NSF IBN0076604, EPA R-82940601, and NSF DBI-0116203.

\section{LITERATURE CITED}

Barbour MG (1970) Is any Angiosperm an obligate halophyte? Amer Midl Nat 84:105-120

Bertness MD, Ellison AM (1987) Determinants of pattern in a New England salt marsh plant community. Ecol Monogr 57:129-147

Bowman WD, Hubick KT, von Caemmerer S, Farquhar GD (1989) Short-term changes in leaf carbon isotope discrimination in salt- and water-stressed $\mathrm{C}_{4}$ grasses. Plant Physiol 90:162-166

Brugnoli E, Lauteri M (1991) Effects of salinity on stomatal conductance, photosynthetic capacity, and carbon isotope discrimination of salt-tolerant (Gossypium hirsutum L.) and salt-sensitive (Phaseolus vulgaris L.) $\mathrm{C}_{3}$ non-halophytes. Plant Physiol 95:628-635

Campbell GS, Norman JM (1998) An Introduction to environmental biophysics, 2nd edn. Springer-Verlag, New York

Drake BG (1989) Photosynthesis of salt marsh species. Aquat Bot 34:167-180

Epstein E (1972) Mineral nutrition of plants: principles and perspectives. John Wiley \& Sons, New York

Farquhar GD (1983) On the nature of carbon isotope discrimination in $\mathrm{C}_{4}$ species. Aust J Plant Physiol 10:205-226

Farquhar GD, Richards RA (1984) Isotopic composition of plant carbon correlates with water-use efficiency of wheat genotypes. Aust J Plant Physiol 11:539-552

Farquhar GD, O'Leary MH, Berry JA (1982a) On the relationship between carbon isotope discrimination and the intercellular carbon dioxide concentration in leaves. Aust J Plant Physiol 9:121-137

Farquhar GD, Ball MC, von Caemmerer S, Roksandic Z (1982b) Effect of salinity and humidity on $\delta^{13} \mathrm{C}$ value of halophytes - evidence for diffusional isotope fractiona- 
tion determined by the ratio of intercellular/atmospheric partial pressure of $\mathrm{CO}_{2}$ under different environmental conditions. Oecologia 52:121-124

Farquhar GD, Ehleringer JR, Hubick KT (1989) Carbon isotope discrimination and photosynthesis. Annu Rev Plant Physiol Plant Mol Biol 40:503-537

Heckathorn SA, DeLucia EH (1991) Effect of leaf rolling on gas exchange and leaf temperature of Andropogon gerardii and Spartina pectinata. Bot Gaz 152:263-268

Helliker BR, Ehleringer JR (2002) Grass blades as tree rings: environmentally induced changes in the oxygen isotope ratio of cellulose along the length of grass blades. New Phytol 155:417-424

Henderson SA, von Caemmerer S, Farquhar GD (1992) Shortterm measurements of carbon isotope discrimination in several $\mathrm{C}_{4}$ species. Aust J Plant Physiol 19:263-285

Henderson S, von Caemmerer S, Farquhar GD, Wade L, Hammer G (1998) Correlation between carbon isotope discrimination and transpiration efficiency in lines of the $\mathrm{C}_{4}$ species Sorghum bicolor in the glasshouse and the field. Aust J Plant Physiol 25:111-123

Jennings DH (1976) The effects of sodium chloride on higher plants. Biol Rev 51:453-486

Long SP, Baker NR (1986) Saline terrestrial environments. In: Baker NR, Long SP (eds) Photosynthesis in contrasting environments. Elsevier, Amsterdam, p 63-102

Meinzer FC, Plaut Z, Saliendra NZ (1994) Carbon isotope discrimination, gas exchange, and growth of sugarcane cultivars under salinity. Plant Physiol 104:521-526

Meinzer FC, Saliendra NZ (1997) Spatial patterns of carbon isotope discrimination and allocation of photosynthetic activity in sugarcane leaves. Aust J Plant Physiol 24: 769-775

Neales TF, Fraser MS, Roksandic Z (1983) Carbon isotope composition of the halophyte Disphyma clavellatum

Editorial responsibility: Otto Kinne (Editor-in-Chief), Oldendorf/Luhe, Germany
(Haw.) Chinnock (Azioaceae), as affected by salinity. Aust J Plant Physiol 10:437-444

O'Leary MH (1981) Carbon isotope fractionation in plants. Phytochemistry 20:553-567

O'Leary MH, Madhavan S, Paneth P (1992) Physical and chemical basis of carbon isotope fractionation in plants. Plant Cell Environ 15:1099-1104

Pennings SC, Bertness MD (2001) Salt marsh communities. In: Bertness MD, Gaines SD, Hay ME (eds) Marine community ecology. Sinauer Associates, Sunderland, MA, p 89-316

Peterson BJ, Howarth RW, Garritt RH (1985) Multiple stable isotopes used to trace the flow of organic matter in estuarine food webs. Science 227:1361-1363

Salisbury FB, Ross CW (1992) Plant physiology, 4th edn. Wadsworth Publishing, Belmont, CA

Sandquist DR, Ehleringer JR (1995) Carbon isotope discrimination in the $\mathrm{C}_{4}$ shrub Atriplex confertifolia along a salinity gradient. Great Basin Nat 55:135-141

Sasakawa H, Sugiharto B, O'Leary MH, Sugiyama T (1989) $\delta^{13} \mathrm{C}$ values in maize leaf correlate with phosphoenolpyruvate carboxylase levels. Plant Physiol 90:582-585

Teal J, Teal M (1969) Life and death of the salt marsh. Ballantine Books, New York

van Groenigen JW, van Kessel C (2002) Salinity-induced patterns of natural abundance carbon-13 and nitrogen-15 in plant and soil. Soil Sci Soc Am J 66:489-498

Walker CD, Sinclair R (1992) Soil salinity is correlated with a decline in ${ }^{13} \mathrm{C}$ discrimination in leaves of Atriplex species. Aust J Ecol 17:83-88

Willmer CM (1983) Stomata. Longman, London

Zhu J, Meinzer FC (1999) Efficiency of $\mathrm{C}_{4}$ photosynthesis in Atriplex lentiformis under salinity stress. Aust J Plant Physiol 26:79-86

Zhu JK (2001) Plant salt tolerance. Trends Plant Sci 6:66-71

Submitted: September 26, 2005; Accepted: February 16, 2006

Proofs received from author(s): March 30, 2006 